\title{
The Use of Market Mechanisms in Higher Education Finance and State Control: Ontario Considered
}

\section{STACEY J. YOUNG}

Ontario Institute for Studies in Education / University of Toronto

\section{ABSTRACT}

Marketization has been so liberally applied to understanding higher education finance policy change that it has become a less potent conceptual tool. Through its evolution as a conceptual tool, the relationship between state control and market control has become an either/or proposition. In Ontario, state control over higher education has been strengthened with the use of market mechanisms, particularly as they have been utilized in resource allocation. This article outlines seven major higher education policy changes that make use of market mechanisms while enhancing state control. It is argued that marketization is a compromise between privatization, academic autonomy, and blatant state control in the face of the backlash against government intrusion in western socioeconomic life.

\section{RÉSUMÉ}

La mise en marché en éducation, ou l'emploi des mécanismes du marché, a été appliquée si libéralement pour comprendre les décisions financières en éducation qu'elle s'est rendue inutile pour décrire l'évolution ou les changements de la politique actuelle. En plus, elle a 
évolué d'une telle façon que le rapport entre le contrôle de l'État et celui du marché est devenu une proposition de l'un ou l'autre. En Ontario, le contrôle de l'État en éducation a été renforcé avec l'emploi des mécanismes du marché, surtout dans le domaine de l'allocation des ressources. Ce document brosse un tableau sur les sept changements les plus importants qui ont utilisé les mécanismes du marché tout en améliorant le contrôle de l'État. On discute la mise en marché comme un compromis entre la privatisation, l'autonomie scolaire, et l'étatisation devant les répercussions contre l'imposition gouvernementale dans la vie socioéconomique de l'Occident.

\section{INTRODUCTION}

In 1974, Larry L. Leslie and Gary P. Johnson wrote of policy change at the federal level in the United States that involved the redirection of federal funds away from universities' operating support to student aid. The authors argue that those changes served to unleash market dynamics in the public higher education sector, measures taken in part to assist the financially ailing private institutions: By introducing greater choice for the student cum customer through an increase in portable subsidies, the troubled private institutions had a greater chance of survival. This, following the market paradigm, would ensure choice and competition in the higher education market, composed of both public and private sectors.

Today the notion of marketization is applied to a host of policy changes which ostensibly seek to make institutions more accountable to their truly vast array of stakeholders: students, employers and the taxpaying public at large, as well as introducing decentralization and the need for an increase in competition for both public and private funds. However, in some camps marketization has become a catch-all to describe reform in a variety of jurisdictions in which universities, still largely state-dependent, are undergoing what are fundamentally minor changes in regulation. For example, the concept has been used to describe recent policy directions in Spain, where universities are realizing some measure of badly needed autonomy from the central state, by delegating to the institutions the power to set curricula, hire faculty and 
respond to the consumer needs of students (Mora, 1997). The reforms were in part a response to the Franco regime's use of universities through a good part of the last century as political tools, which placed these institutions in a position of complete dependence upon the state (p. 188). After the restoration of democracy in 1978, reform of the relations between the state and universities was regarded as a priority on the part of both academics and government. In 1983, the Ley de reforma universitaria [University Reform Act] granted Spanish universities autonomous status, rendering them accountable to Spain's autonomous regional authorities in place of the central government. However, with the continued role of the regional state in regulating, controlling and financing the system, 'marketization' has been hastily applied to a system that is merely removing some of the instruments that had allowed the former dictator to take such as firm grasp of the nation's universities.

More fatal to the integrity of the notion of marketization as a meaningful analytical tool in understanding higher education reform is the 'either/or' proposition upon which it often rests. Observations of global trends in higher education at times fail to capture the multi-layered and sometimes seemingly contradictory nature of policy change. For example, the fatal flaw of such works as Goedegebuure et al.'s (1993) review of higher education policy change in western Europe is this either/or proposition. In noting the general direction of changes in the relationship between academic autonomy, the market and the state, the authors note:

If the push towards institutional competition, de-regulation, and privatization is a pervasive and long-term trend, then it is an interesting phenomenon indeed, for it appears to represent a reversal of governments' attitudes in their relationship with higher education. Trow... notes that during the 1950s, 1960s and 1970 s most Western governments were not willing to trust to the private sector the achievement of basic social goals... (p. 324)

Is marketization a long-term and long-lasting shift in university finance policy? That is, of course, unknown. It may even prove to be as short-lived as the block grant. However, the problem with the question is that it is perhaps the least important one, for it fails to take account of 
how markets and governments work in tandem, and, further, how the market paradigm simply adds yet another instrument to the state's already formidable tool box that assists it in regulating and controlling higher education. In other words, the introduction of market mechanisms does not exclude an increase in government control, but rather a change in the nature of the inducements the state may offer to 'encourage' universities to adopt government identified priorities and activities. It is suggested, then, that there may in fact be no reversal of government attitudes per se, but that governments have simply 'discovered' a new way of organizing reform and control.

An examination of policy change in several jurisdictions, particularly in the Commonwealth countries, demonstrates that more is going on than simply a matter of governments renouncing control over universities to the market. Though in decades past it may have been true that the achievement of social goals was not assigned to the private sector, today many western governments are far too interested in the role universities can play in economic growth to allow them to reside entirely outside their grasp. The competitive edge universities provide to national and regional economic centres by producing a highly educated and trained labour force - not the mention their role as knowledge producers - is far too valuable to government and their economic growth strategies, even to those governments bent on cost-cutting.

Thus marketization represents a neo-Liberal, late-20th century compromise between privatization, the 'autonomous' university that is removed from all social and economic forces, and blatant government control in the face of the backlash against state intrusion in western socioeconomic life. For their part, market mechanisms are viewed by governments as a way of assisting them in allocating resources, where either government failure or market failure threaten either efficient allocation, or in the latter case, a resultant loss of state control over outcomes.

\section{THE MARKET DEFINED}

Market relations and market exchange, simply defined, involve two parties which voluntarily contract to exchange a good or service for a socially or legally recognized currency. According to many of its learned 
and most articulate spokespeople, it is in this simplicity that its merits are most strongly evident. Markets are expressions of a "spontaneous order," and are an outgrowth of evolutionary processes and pressure (Hayek, 1976). The market is not a product of a human desire to create grand, strongly centralized and articulated systems, nor can the nature of markets be understood outside or beyond the act of exchange between two parties. Thus Hayek warns of the tendency to confuse the "market" with the "economy," the latter constituting a network of economic activity, which may include both market and non-market forms of production and distribution. An economy, rather than a market, may even imply a shared "hierarchy of ends" (p. 108), whereby government (non-market) and market mechanisms co-exist to bring about certain social, economic or political ends perceived as outside the capability of a free market. Therefore, an economy is, simply, an aggregate of all market and nonmarket activity.

Indeed, to market economists, the merits of markets and market economies can only be understood on this micro exchange level. Thus, given the centrality of the individual and the exchange which takes place between individuals in the absence of coersion, market-based economies are considered by their most enthusiastic proponents as necessary conditions to the creation and preservation of the freedom and liberty of a given society's individual members, applicable to both the political and social arenas (Shipman, 1999, p. 13). According to Hayek (1976), "[it] is often made a reproach to the Great Society and its market order that it lacks an agreed ranking of ends. This, however, is in fact its great merit which makes individual freedom and all its values possible" (p. 109). Hayek states:

Although there is good reason for preferring limited democratic government to a non-democratic one, I must confess to preferring non-democratic government under the law to unlimited (and therefore essentially lawless) democratic government. Government under the law seems to be the higher value (Hayek in Marginson, 1993, p. 61).

A market is a loose network composed of unorganized individuals able to access the information necessary to make rational choices. 
Competition - the "confrontation between agencies endowed with calculating tools of differing levels of efficiency" (Callon, 1997, p. 32) - is its primary "discovery procedure," the essential way in which quality and value are assessed and made apparent. Of the various information cues available to the economic actor, price is a critical one, acting as "information in coded form," important given the varying wealth capacities and buying power of individual consumers (quoted in Haworth, 1994, p. 117).

Efficiency - even the improvement in the 'relative position of those in the lowest income groups' resulting from the 'general growth of wealth' - is facilitated by the fact that prices indicate 'which of the available technical methods is most economical in the given circumstances.'

\section{EMERGING MARKETS IN HIGHER EDUCATION}

Having briefly revisited what constitutes markets and market relations, we are reminded of the requisite degree of care and qualification in applying the notions to the realm of higher education systems. No doubt economists would denounce the use of the concept in relation to higher education altogether. The existence of portable subsidies, the lack of a clear relationship between price and cost, and the exertion of state control in nearly all systems of higher education, preclude the operation of markets, perfect or otherwise. It remains, however, of some use. Its utility lies in part in a sort of extension or re-evaluation of Clark's (1983) triangle of co-ordination, a concept which recognizes that there are in almost every system three forces that serve to shape all systems of higher education: (1) the forces of the market; (2) the forces of academic control, or the 'academic oligarchy'; and, (3) the role played by the state in regulating and controlling systems. This combination of forces at play speak to the relative influences of one over the other in different systems, or in the same system over time. Thus this triangle can be used as a way of considering shifts in the relative strength of one organizing principle over another. And though Clark wrote of private and not of public markets, the triangle can be considered an instrument in recognizing the ways in 
which the dominance of the state gives way - in large or small part - to the dominance of market forces, or that the power of academics is diminished at the expense of that of a combination of market and state influence.

Before beginning an examination of how the notion of markets and marketization have been conceived, shaped and reshaped in the education finance literature, I will note some of the arguments made that must qualify the application of the concept of the market in the context of higher education, and whether or not the concept can be applied at all. An attempt will also be offered to explain how marketization accounts for a variety of changes in the public sector, which make it a more appropriate analytical framework for understanding university policy change in the context of Ontario.

\section{MARKETIZED COMPARED TO WHAT? RELATIVE MARKET FORCES IN HIGHER EDUCATION}

A fair degree of consensus exists that there is no such thing as a perfect market in higher education (Breneman, 1981; Dill 1997a, 1997b). Equally strong arguments suggest that the operation and utilization of market principles is fairly weak, as Breneman (1981) argues below:

- That institutions (as "firms") are not motivated by profit, but rather by maximizing the indices of status and prestige.

- That price fails as a reliable signal of either the product's quality or actual cost.

- That evidence suggests quite strongly that the student-consumer operates in a 'market' in which there is largely insufficient information regarding the range of products and the implications of purchasing one product over another, and that a student's capacity to correct an error in purchase is weak.

- That the range of subsidies that are offered public institutions in contrast to private firms remove the possibility that comparisons can be made for "comparable services" in the two sectors. (p. 25)

Of course, a perfect market does not exist even in the private sector, but rather only in the abstract. Thus, if the achievement of a perfect 
market is difficult in the case of the market in guns, or the market in butter, it is even more the case with higher education. In most countries, higher education is recognized as both a public and a private good, and thus financing arrangements reflect this insofar as both public moneys and private moneys are used to fund the sector. Subsidies in some form or another - including federal government and other sources of funding for research; regional, state or federal subsidies channelled directly to students in the form of portable grants, loans and other forms of student aid; or tax payer support for operating grants - are near universal in some measure. So what is meant by marketization in higher education?

According to the Organisation for Economic Co-operation and Development, member countries are either adopting or contemplating: (1) the adoption of more sophisticated formulae for allocating funds for teaching and research; (2) developing separate mechanisms for funding teaching and research; (3) increasing the role student fees play in financing the system; and, (4) implementing more competitively based 'bidding' schemes for public funds (OECD, 1990, p. 79). These policies serve to require institutions to engage in "competition for moneys, whether these are for external grants and contracts, endowment funds, university-industry partnerships, institutional investment in professors' spin-off companies, or student tuition and fees" (Slaughter \& Leslie, 1997, p. 11). A longer list of indices of market-like behaviour includes the sale of educational services and products, and substantive institutional reorganization, including administrative, that better supports the successful procurement of competitively allocated funds, both external and internal in source (passim).

In their work, Academic Capitalism, Slaughter and Leslie (1997) take up the question of institutions' increasingly entrepreneurial behaviour. The choice of titles for their work was informed by human capital theory, in which faculty as highly skilled labour constitute one of the three factors of production, and as such contribute to economic growth. It is through this lens that they view what they see as the increasingly entrepreneurial activity of faculty members themselves, as they progressively harness the resources and administrative apparatuses of universities to market their wares, work with spin-off companies and their marketing 
arms, and draw on the same offices to compete for and obtain funds from both public and private sources, internal and external. "Their [faculty] scarce and specialized knowledge and skills are being applied to productive work that yields a benefit to the individual academic, to the public university they serve, to the corporations with which they work, and to the larger society" (Slaughter \& Leslie, 1997, p. 11).

The process of globalization provides the backdrop to the changes in university finance that are described and documented by Slaughter and Leslie. The combination of the opening of global financial markets, the rise of supra-national trade protocols and governance bodies, combined with the relative decline of the nation state means that pressures to reduce social spending in one nation become pressures of similar magnitude in a trading partner. This higher education reform, argue Slaughter and Leslie, is a consequence of the expansion of world markets, and has led to the creation of tighter linkages between universities and the marketplace in terms of an emphasis on science and technology research with commercial applications, as well as increasing the production of graduates in fields that enjoy a proximity to the market. Set against these global trends and pressures is the status of the unconditional block grant, reduced in part as a response to these pressures. Slaughter and Leslie argue that the relative decline in the block grant - which constituted a large and important source of universities' operating income - creates a destablized environment for universities, resulting in resource dependencies. According to resource dependence theory, external agents that provide the bulk of funds to an institution wield substantial control, thus internal members of an organization are dependent upon those of external agents (Pfeffer as cited in Slaughter \& Leslie, 1997). Institutions such as universities interact with and depend on the external agents who control the distribution of the resources on which the universities depend. Internal agents of a dependant organization expend considerable amounts of time, energy and resources strategizing as to how best to obtain the resources held and distributed by external agents. "Negotiating exchanges to ensure the continuation of needed resources is the focus of much organizational action" (Pfeffer as cited in Slaughter \& Leslie, 1997, p. 258). Thus, a reduction in the form of U.S. federal 
funding for postsecondary education, from a shift in the relative emphasis on the block grant to a user subsidy such as student aid, would require institutions to shift their energies to make up for that lost income:

Universities seek to capture alternative revenues. But substitutes often carry stipulations; they require the performance of certain tasks. Collectively and individually, faculty perceive their greatest potential source of additional revenues to be in grants and contracts with government and with the private sector. Taking government block grants (as well as tuition fee revenues) as a given, they focus any marginal (additional) efforts on proposal writing, patenting, and developing and maintaining relations with potential funders. (Slaughter \& Leslie, 1997, p. 71, italics in original)

The centrality of the notion of competition, implied in the scramble to make up for lost funds from black grant reductions, is also emphasized in the work of Dill (1997a, 1997b). Universities, he argues, now operate in numerous markets, for professors, students and research funds. Add to this the delegation of authority to institutions themselves accompanied by greater accountability controls on the use of funds (Dill \& Sporn, 1995, p. 3). In contrast to Slaughter and Leslie's emphasis on the development and process of marketization, with the importance they place on resource dependency theory and the "domino effect" of shifts in resource dependence, Dill focuses on the attraction of the perfectly competitive market as a guide to reforms within higher education, particularly in the U.S., in an effort to achieve more efficient and equitable allocation of higher education.

Dill (1997b) provides four examples of public policy trends in global higher education financing patterns that exhibit a reliance on, and derive theoretical coherence from, the logic of markets. The first, encouraged by the economists of such global organizations such as the World Bank and UNESCO, is the trend toward "leveling the playing field" between private and public institutions through the deregulation of the public sector, and directing increasing subsidies to the systems' users. The theory behind such a move is that in so doing, developing countries can more easily shift from an elite to a mass system, in the face of severe limitations on public spending. 
Dill's second example of marketization or 'strain' is the creation of "quasi" markets in higher education, as in Britain, in which essentially the principles of competition are imported into public-funding allocation models. The third, and one increasingly a reality in both North American and European systems, is the requirement of institutions that they release greater amounts of information to the student-consumer, and develop mechanisms for achieving greater accountability for how these institutions use their funds. And lastly, the tendency, also a global phenomenon, that universities increase user fees in public systems, decrease institutional operating support and increase the funds available for student aid programs (Dill, 1997b).

Like Slaughter and Leslie, Dill argues that universities and the governments that fund and regulate them are under increasing pressure to change the way public investments are made. To improve efficiency and make institutions more adaptable to the changing expectations of the global economy, importing market mechanisms are viewed as a superior means to achieving these changes than were more traditional ways. Higher education reform that exploits the tools of the market is in part a response to perceived government failure to rationally or efficiently determine supply, demand or the distribution of educational resources, and is achieved through the relaxation of regulatory regimes and the devolution of responsibilities to institutions themselves.

However, consistent with Dill's emphasis on viewing government as a less than silent partner in the process of creating and stimulating markets, he asserts that relaxing regulation in one area may create increased government control, or at the very least greater involvement, in another area. For example, in the process of delegating discretion to the institution for finances or fee levels may also bring additional rules for accounting for the ways in which funds are used, as is the case, he asserts, in the U.S. and the U.K. A further example is provided by Ontario. In that province, universities have been granted greater freedom to set tuition fees in certain areas in exchange for directing a portion of fee increases to institutional student aid programs.

An important means of how governments control, interact with, and shape markets is through regulation. Regulatory measures exist in higher 
education largely to control the behaviour of sellers in the market, and are concerned largely with the prices of various services provided by institutions. One of the major forms of regulation concerns tuition fees, and has been used by various governments to control the forces of supply and demand for undergraduate education. Governments do this through a variety of means, including tying the fee increase permitted to the operating grant, so that tuition fee increases over a certain government mandated level results in a reduction in the operating grant (they may, of course, also simply set the fee). Other potential means of penalizing institutions is to deny their students access to student assistance programs or limit the funding of a number of spaces in such high-cost programs as medicine or dentistry (Dill, 1997b).

Comparing Slaughter and Leslie's conceptions of markets in higher education produces no excessive degree of conflict and tension, but rather a markedly different emphasis. Dill's investigation of the manner in which governments participate in the shaping, creation and stimulating of market forces admits of a greater recognition of the important role governments play in higher education markets. Governments continue to have a stake in the contribution of universities to national and regional economies. As Dill and Sporn (1995) argue, "major universities, which in all countries, even in the United States, are increasingly seen by their governments as being among the remaining few and strategically most important state enterprises" (p. 1). In this respect then, the idea of markets provides a framework for change in the redesign and reconstruction of university finance policies. It is, however, in most jurisdictions the state that draws the blueprints of change and remains the architect of change.

In Slaughter and Leslie (1997) and Leslie and Johnson (1972), marketization is a domino effect that begins with the initial reduction in the block grant and the subsequent institutional attempts to make up for lost funds. Their treatment of the process suffers to some extent of reductionism, in which institutional actors shift energies in the face of declines in block grants and governments are relegated to the back seat in steering the direction of universities. In contrast, Dill's approach allows three dimensions of marketization that are not permitted in Slaughter and Leslie's work. 
1. That the market and the logic of perfectly competitive markets functions as an ideological construct, a political option that in the last twenty years, and in particular since the fall of the Soviet Union, is enjoying a renaissance, even within the context of the public sector.

2. That an emphasis on the partnership between governments and markets allows for the myriad ways in which the creation of markets does not necessarily entail a more distanced relationship between the state and higher education institutions.

3. That this notion of marketization that recognizes its facets, degrees and continued relationship with the state is precisely what makes this a fundamentally different experience than privatization.

The dominance of the market as the organizing principle of the world economy today (Haworth, 1994; Kuttner, 1997; Shipman, 1999) serves to make its political dimensions virtually invisible. However, its ideological dimensions, the market as an ideological expression, must be recognized, and is evident in the hopes which are hung on market economies on the part of its most virulent proponents. In other words, the market is a panacea for a host of unpleasantries, ranging from totalitarianism and communism (à la Friedman, 1945; Hayek, 1976) to the under investment in professional education (Friedman, 1945) to government deficits and debt (Meek 1997). It is spoken of lovingly in grandly therapeutic ways. It is regarded by some as the most superior moral, economic and philosophical order. Harnessing the market (including its cousin, privatization) for the purposes of ordering higher education "is advanced as a kind of medicinal compound which is most efficacious in every case" (Rae, 1997, p. 60). To others, however, "in the post modern financial jungle, 'the market is a predator. It looks around for a vulnerable currency and strikes it, unmercifully, like a cobra"' (in Kenway, Bigum , \& Fitzclarence, 1993, p. 120). This ideological dimension and its use by the state are both facets of marketization that are downplayed in the work of Slaughter and Leslie (1997), but are nonetheless important in understanding its many nuances. 


\section{RECENT ONTARIO HIGHER EDUCATION FINANCE POLICIES CONSIDERED}

Ontario perhaps provides one of the best examples of how the twin strategies of state control and the use of market mechanisms converge, apparent in an examination of recent policy changes in that province. Beginning in 1995, with the election of the Progressive Conservatives, the Tory government proceeded to reorganize local government, consolidate control over elementary and secondary school and delegate other social services to local government, in addition to cutting social spending and corporate and personal income taxes. These policy shifts are occurring amidst a process whereby Ontario is undergoing a process of transformation "from heartland to region state" (Courchene \& Telmer, 1998). This process entails a number of policy and fiscal changes, both internal and external, that have recast the province's previous role as most privileged province in the Canadian federation to a more self-interested, semi-independent nation-state. The provincial Tories have turned their attention in different directions - both inward and outward: inward of terms of crafting social and industrial policy as if it were an independent state, and outward in the sense that many of its policies are intended to increase its own position of competitiveness in the global, as opposed to the Canadian, economy.

Associated with this key thrust is a shift toward markets (downsizing, privatizing, deregulation) and towards enterprise at both the business and individual level. The broad catalysts for all of this were two-fold - at the internal level, a reaction to the deemed excesses on the debt/deficit, tax and redistributional fronts triggered by the Peterson/Rae eras, and, that the external level, a buying into the implications and irreversibilities ushered in by globalization and the knowledge/information revolution (Courchene \& Telmer, 1998, p. 213-214).

In their insightful study of Ontario's reorientation of Ontario as cityor nation-state, the the authors further note that though spending cuts have in part reduced the overall size of government, the province has assumed a strong interest in the design features of a number of policies 
of which the federal government has previously been the exclusive architect, such as the Canada Pension Plan and Employment Insurance and training. They argue that the trends they have identified are due to a combination of forces, and their description of those trends is entirely consistent with what Cameron and Stein (2000) term the movement of political control "up, down and away from the nation state" (p. S16).

Against this backdrop, the Ontario government have pursued policies in university finance which deem any stakeholder attempts to appeal to 'national averages' a wasted effort. Change, and 'revolution' of the common sense variety in the direction of greater competitiveness was their first order of business. The principles of competition, partial deregulation and creating greater synergy between universities and the private sector are embodied in the following seven policy highlights:

1. Changes in tuition fee policy and regulation: While the government permitted the basic arts and science fee to increase at the discretion of the universities to $133 \%$ of the formula fee, graduate programs in all areas were deregulated, as well as programs in engineering, law, medicine, dentistry, management, education (the M.Ed. and Ed.D. streams), and all other programs deemed 'professional,' including museum studies and the master's program in public health;

2. Changes in provincial allocations direct to the universities, and the increasing importance of other sources of income;

3. Information dissemination requirements, based on the assumption that markets are more 'perfect' when greater amounts of information are accessible that may inform consumer choice. In related policy, a small portion of grants (about $2 \%$ ) are tied to the institution's ability to remain below certain levels in terms of the student loan default rates. There are three indicators: default, graduation and employment rates;

4. The Ontario Student Opportunities Trust Fund, intended to increase the amount of student support funds available to needy students. It was also a matching program in which the government of Ontario matched all funds raised in the private sector for student aid; 
5. The Access to Opportunity Program, an initiative to 'double the pipeline' of computer science and engineering graduates. This program was conceived of by an IT sector lobby group, which put forward a proposal that the government match all funds raised by the private sector toward expanding the number of student spaces in these fields;

6. The Ontario Research and Development Challenge Fund, in which the provincial government would contribute one-third of total funds required to support research initiatives that have secured private sector financing;

7. New law and policy that enable the establishment and approval of new private, degree-granting institutions and programs.

Considered together, these policies derive considerable coherence from the idea of the market: the effort to bring cost and price in the form of tuition into greater alignment; the information dissemination requirements; the encouragement of new, private degree-granting institutions; encouraging more synergy between the market and universities' research enterprise through the mechanism of matching-fund programs. However, two policies in particular illustrate the concerns of the government that it not forfeit control over universities' spending and investment priorities, and further, how it may combine the use of market mechanisms as additional levers to enhance government control.

First, the Ontario Student Opportunity Trust Funds. The OSOTF initiative was announced in the budget speech in May of 1996 by the minister of finance. Each dollar raised by the colleges and universities within a specified time period would qualify for matching funds from the province. The government's stated purpose for mounting this program was to encourage private sector investments, from companies and individuals, to "invest in support for academically qualified individuals who for financial reasons would not otherwise be able to attend college or university" (Guidelines for Ontario Student Opportunity Trust Funds, August 1996). When the program was announced, $\$ 100$ million was set aside for distribution to the provinces and colleges, however at the end of the allotted time period, universities had managed to raise approximately $\$ 266$ million (of that amount the University of Toronto garnered \$114 
million) and the community colleges approximately $\$ 47$ million. Since there was no bidding process, no sector shares worked out, this meant one university's (and college's) success had greater potential to translate into another one's failure.

The manner in which the market allocated funds for student aid is noteworthy, which is represented in Table 1. Table 1 is a comparison of the percentage of funds raised by each institution, their share of provincial enrolment, and the institution's percentage of OSAP-dependant students. The amounts raised by four universities mirror very closely their share of provincial enrolment (Laurentian, Nipissing, Trent and York). Six universities out of 18 surpassed their share, though in four cases it was by extremely marginal amounts (Guelph, Hearst, McMaster, Queen's, York and Toronto). The University of Toronto raised roughly $43 \%$ (or $\$ 95$ million) of the total, while enrolling $17 \%$ of the province's university students. Queen's University managed the second best result, raising almost $13 \%$ of total funds while enrolling only $5.7 \%$ of Ontario's university students.

There are several potential rationales behind this program: offering this one-time only student aid program allowed the government to shift some of the costs away from the provincial loan program, since OSOTF funds as well as others totalling $\$ 600$ and above would serve to decrease a student's loan entitlement. However, it can be seen to enhance the potency of the market insofar as it increased the resources of individual universities in competing for, and recruiting, students and their tuition revenue.

The influence of the market is clearer in terms of its role in the allocation of resources under the program: The government called upon the market to assist it in determining the distribution of public funds made available for the program. The government chose not to distribute funds on the basis of full-time enrolment, or use the funds to enrich OSAP, the province's loan program. Instead, it chose to 'contract out' the task of allocating the funds to the donors who would fund the program. And finally, the program served to foster competition among universities for what is inarguably a finite amount of philanthropic dollars, and had the private sector determine institutional entitlement to tax-payer dollars. 
Table 1

Funds raised through the Ontario Student Opportunity Trust Funds Program

\begin{tabular}{lrccc}
\hline Institution & $\begin{array}{c}\text { Dollars } \\
\text { Raised }\end{array}$ & \% of funds & $\begin{array}{c}\text { \% Provincial } \\
\text { Enrolment }\end{array}$ & $\begin{array}{c}\text { \% of } \\
\text { OSOTF }\end{array}$ \\
\hline Brock & $3,823,061$ & 1.4 & 3.2 & 4.3 \\
Carleton & $8,795,324$ & 3.3 & 6.3 & 6.3 \\
Guelph & $10,386,310$ & 3.9 & 4.7 & 5.4 \\
Lakehead & $3,251,601$ & 1.2 & 2.6 & 2.1 \\
Laurentian & $5,973,447$ & 2.2 & 2.5 & 2.4 \\
McMaster & $14,383,128$ & 5.4 & 5.9 & 5.5 \\
Nipissing & $1,714,621$ & 0.6 & 0.8 & 1.2 \\
OCAD & 250,895 & 0.1 & 0.7 & 1.0 \\
Ottawa & $7,733,647$ & 2.9 & 7.4 & 5.8 \\
Queen's & $34,607,513$ & 13.0 & 5.7 & 4.9 \\
Ryerson & $2,817,497$ & 1.1 & 6.0 & 5.8 \\
Toronto & $114,234,007$ & 42.9 & 17.0 & 16.2 \\
Trent & $2,785,520$ & 1.0 & 1.8 & 2.4 \\
Waterloo & $3,237,891$ & 1.2 & 6.5 & 7.0 \\
Western Ontario & $18,328,278$ & 6.9 & 9.5 & 9.7 \\
Wilfrid Laurier & $2,271,182$ & 0.9 & 2.6 & 3.3 \\
Windsor & $2,802,632$ & 1.1 & 4.6 & 4.6 \\
York & $28,906,902$ & 10.9 & 12.0 & 12.1 \\
\hline & $266,303,456$ & $100.00^{*}$ & $100.00^{*}$ & 100.00 \\
\hline
\end{tabular}

* Figures do not add due to rounding.

Sources: "Funds raised through OSOTF," Ministry of Education and Training; Enrolment by Institution figures derived from COU, Compendium of Statistical and Financial Information, 2002.

The Canadian Journal of Higher Education

Volume XXXII, No. 2, 2002 
The second program considered here is the Access to Opportunities Program. In its 1998 budget, the provincial government pledged $\$ 150$ million, later increased to $\$ 228$ million, to universities and colleges in order to induce them to double the number of spaces in information technology (IT) programs (electrical and computer engineering and computer science) in Ontario colleges and universities. This one-time-only sum of $\$ 228 \mathrm{mil}$ lion was designed to allow universities to expand their physical and building capacity required to accommodate the increase of precisely $100 \%$ in the number of spaces (and to a lesser extent faculty), for laboratory space, teaching facilities and faculty offices. Eligibility for the program required universities to submit relatively detailed financial and academic plans to the provincial government by November, 1998. In addition, there was a yet-to-be-determined amount of earmarked base budget funding available to hire and retain the new faculty required. The $\$ 228$ million ATOP fund was allocated among universities using two main criteria: (1) a university's share would be based on its share of IT programs enrolment, and (2) that universities successfully raise the equivalent of their matching dollar share from the private sector before April 1999.

This program was proposed by Ontario-based, Canadian IT companies to the province of Ontario in its matching-fund form after the industry's failure to influence federal immigration policy, in the direction of facilitating the entry of greater numbers of skilled foreign-born IT workers. In February of 1998, CATA submitted to the provincial government a detailed plan to increase the number of undergraduate IT spots in Ontario universities, premised on provincial investment that would be used to leverage financial support from the lobby group's membership. In the proposal, the association estimated that Ontario would require more than 56,000 new IT workers by the year 2000 , against the available pool of 14,000 - a shortfall of 42,000 (CATA, 1998).

In order to stress the serious nature of the skills shortage, CATA issued a not-so-veiled threat. "Unfortunately, our members are telling us that there is now a strong likelihood that some, if not much, of this growth may be destined for offshore. While locations decisions are always complex, the availability of highly trained knowledge workers is becoming the driving force for these matters" (CATA, 1998., p. iii). In 
other words, if the government refused to invest in high-technology training at some public expense, this IT sector would seek out other manufacturing centres which possessed more readily available pools of qualified technology workers.

The government responded with an announcement to participate quickly. Indeed, the haste with which the government pursued this proposal invited what could only be considered a rather dubious form of praise. In the words of the then-executive director of CATA:

...normally such a program would be announced and then disappear for six to twelve months while the bureaucrats worked on the details. Our hat is off to the government and its officials for working in real time, and delivering the program in less than $\mathbf{3 0}$ days. Never before have we seen a government as responsive to the warp speed time frames needed to keep pace with the technology community. This will allow the postsecondary institutions to dramatically increase their enrolments this fall. (CATA news release, May 1998)

Unlike the OSOTF program, the initiative itself, that is, large scale expansion of the number of IT-training spots, came from the private sector and the community of potential funders. And though presumably program funders would not have a say over what is taught in these IT programs, funders did in fact have a say over the design of the program insofar as the matching program was concerned. In this case, the government in fact responded to a stated need among the private sector, and less the demand expressed by student-consumers, and adopted design parameters for the program would preserve choice among potential funders in determining the distribution of resources that would fund the expansion.

That there will never be sufficient ways or space qualifying the application of the concept of the market in higher education, it is suggested here that the example of Ontario adds to our understanding of how marketization may be accompanied by enhanced state control. However, as Slaughter and Leslie (1997) point out in Academic Capitalism:

Of course, the word capitalism connotes private ownership of the factors of the means of production - land, labour, capital - and considering employees of public universities to be 
capitalists at first glance seems a blatant contradiction. However, capitalism is also defined as an economic system in which allocative decisions are driven by market forces. (p. 9)

\section{CONCLUSION}

Ontario provides a case study in marketization that demonstrates its use as a conceptual tool in elucidating the ways in which governments employ market mechanisms to assist it in the allocation of resources without forfeiting complete control over university systems. Despite its overuse or excessively liberal application, the notion of marketization permits an understanding of recent university finance policy change in Ontario not afforded by the notion of privatization. With this understanding, it is possible to see recent policy changes as embodying a compromise between academic autonomy and the total forfeiture of the power of the state in an atmosphere of general distrust of government control over western socio-economic life. $\bullet$

\section{References}

Breneman, D.W. (1981). Strategies for the 1980s. In J.R. Mingle (Ed.), Challenges of retrenchmen. San Francisco, CA: Jossey-Bass.

Callon, M. (1998). Introduction: The embeddedness of economic markets in economics. In M. Callon (Ed.), The laws of the markets. Oxford: Blackwell Publishers.

Cameron, D., \& Stein, J.G. (2000). Globalization, culture and society: The state as place amidst shiftin spaces. Canadian Public Policy - Analyse de Politiques, 26, Supplement (August), S15-S34.

Canadian Advanced Technology Association. (1998). Double the pipeline: A proposal for doubling the enrollment in Computing Science/Engineering and Electrical Engineering. Draft Proposal.

Clark, B.R. (1983). The higher education system: Academic organization in cross-national perspective. Berkley, CA: University of California Press. 
Courchene, T.J., \& Telmer, C.R. (1998). From heartland to North American region state: The social, fiscal and federal evolution of Ontario: an interpretative essay. Toronto, ON: University of Toronto, Faculty of Management. Monograph Series on Public Policy and Public Administration, No. 6.

Dill, D.D. (1997a). Markets and higher education: An introduction. Higher Education Policy, 10, 163-166.

Dill, D.D. (1997b). Higher education markets and public policy. Higher Education Policy, 10, 167-185.

Dill, D.D., \& Sporn, B. (1995). The implications of a post-industrial environment for the university: An introduction. In D.D. Dill \& B. Sporn (Eds.), Emerging patterns of social demand and university reform: Through a looking glass darkly (pp. 1-19). Oxford: Pergamon Press.

Friedman, M., \& Kuznets, S. (1945). Income from independent professional practice. New York, NY: National Bureau of Economic Research.

Geodegebuure, L., Kaiser, F., Maassen, P., Meek, L., van Vught, F., \& de Weert, E. (1993). International perspectives on trends and issues in higher education policy. In L. Geodegebuure et al. (Eds.), Higher education policy: An international comparative perspective. Oxford: Pergamon Press (XX-XX).

Hawarth, A. (1994). Anti-libertarianism: Markets, philosophy and myth. London: Routledge.

Hayek, F. (1976). Law, legislation and liberty: The mirage of social justice Vol. 2. Chicago, IL: University of Chicago Press.

Kenway, J., Bigum, C., \& Fitzclarence, L. (1993). Marketing education in the postmodern age. Journal of Education Policy, 8, 105-122.

Kuttner, Robert (1997) Everything for sale: The virtues and limits of markets New York: Knopf

Leslie, L.L., \& Johnson, G.P. (1972). The market model and higher education. Journal of Higher Education, 45, 1-20.

Marginson, S. (1993). Education and public policy in Australia. Cambridge:Cambridge University Press.

Meek, L.V., \& Wood, F.Q. (1997). The market as a new steering strategy for Australian higher education. Higher Education Policy, 10, 253-274.

Mora, J.-G. (1997). Market trends in Spanish higher education. Higher Education Policy, 10, 187-198.

Organisation for Economic Co-operation and Development. (1990). Financing higher education: Current patterns. Paris: OECD.

Rae, P. (1997) New directions: Privatization and higher education in Alberta. The Canadian Journal of Higher Education, 26, 59-80. 
Shipman, A. (1999). The market revolution and its limits: A price for everything. London: Routledge.

Slaughter, S.A, \& Leslie, L.L. (1997). Academic capitalism: Politics, policies, and the entrepreneurial university. Baltimore, MD: John Hopkins University Press. 